\title{
Feeding ecology of yellow-legged gulls Larus michahellis in the western Mediterranean: a comparative assessment using conventional and isotopic methods
}

\author{
Raül Ramos ${ }^{1, *}$, Francisco Ramírez ${ }^{1}$, Carolina Sanpera ${ }^{1}$, Lluís Jover ${ }^{2}$, Xavier Ruiz ${ }^{1, \mp}$ \\ ${ }^{1}$ Departament de Biologia Animal (Vertebrats), Facultat de Biologia, Universitat de Barcelona, Av. Diagonal 645, \\ 08028 Barcelona, Spain \\ ${ }^{2}$ Departament de Salut Pública, Facultat de Medicina Universitat de Barcelona C/Casanoves 143, 08036 Barcelona, Spain
}

\begin{abstract}
Accurate determination of feeding habits using only conventional dietary analysis is usually difficult, due to both biases caused by prey digestibility differences and to the discrete aspect of the sampling. However, combining conventional methods with stable isotope analysis provides an integrated view of the assimilated diet. Here, we measured stable isotope ratios of carbon $\left(\delta^{13} \mathrm{C}\right)$, nitrogen $\left(\delta^{15} \mathrm{~N}\right)$ and sulphur $\left(\delta^{34} \mathrm{~S}\right)$ in feathers of yellow-legged gull Larus michahellis nestlings from 4 colonies along the western Mediterranean coast, where the gulls consume different proportions of marine, terrestrial and garbage resources. We collected and analysed chicks' regurgitates in each colony, thereby determining the isotopic signatures in a significant sample of prey. By applying a mixing model to our isotopic values, we compared the information provided by the 2 methodologies. According to direct prey sampling and the particular conditions of the breeding areas, populations with more enriched $\delta^{34} \mathrm{~S}$ values consumed a diet richer in marine prey, with lower $\delta^{15} \mathrm{~N}$ signatures indicating garbage consumption. The main pattern resulting from the mixing model agreed with direct diet sampling. However, estimated proportions for small-sized prey were controversial, which indicates that small, soft prey items might be underestimated by regurgitate analysis. We conclude that stable isotope signatures and the use of mixing models are useful tools for the rapid assessment of feeding ecology in certain populations. Solving analytical biases should be considered in future feeding studies, thereby saving time and minimising bird disturbance by using an isotopic methodology.
\end{abstract}

KEY WORDS: Carbon-13 $\cdot$ Mixing models $\cdot$ Nitrogen-15 $\cdot$ Regurgitate $\cdot$ Sulphur-34

\section{INTRODUCTION}

Accurate knowledge of diet composition is mandatory in several key areas of applied ecology, such as the management of problematic species and the use of a species to monitor the environmental impact of pollutants. The direct sampling method of reconstructing diets suffers from several drawbacks that hamper the applicability of results (Duffy \& Jackson 1986,
González-Solís et al. 1997, Barrett et al. 2007). Diet studies based on field observations are biased toward the most conspicuous prey. Prey are difficult to identify from gut contents or regurgitates, which are often partially digested (but see Cherel et al. 2007). Moreover, such studies might also be biased toward prey types that are more resistant to digestion, leading to overestimation in the final reconstructed diet (González-Solís et al. 1997, Votier et al. 2003) or proving inapplicable 
because of the intrinsic characteristics of some food types (e.g. pieces of meat and garbage taken at refuse dumps). These methodologies provide only an episodic view of an individual's diet, since each sample represents only a specific feeding event (Votier et al. 2001). Thus, to obtain reliable information about a population's feeding habits, exhaustive monitoring over time is needed (Jordan 2005). However, conventional approaches are still required when we need to identify the taxonomic group of prey consumed. Regurgitated food appears as the least biased method for describing diet composition (González-Solís et al. 1997).

The use of stable isotope analysis (SIA) in animal ecology has increased enormously in recent years and has become an important tool to study trophic ecology (Hodum \& Hobson 2000, Post 2002). Although SIA does not provide the taxonomic detail achieved by conventional dietary analysis, it avoids prey digestibility biases because it only takes into account assimilated food. Moreover, it provides a ready-made integrated estimate because the assimilated diet for a certain period of time is summarised, depending on the tissue analysed (Hobson 1999). Stable isotopes of carbon $\left({ }^{13} \mathrm{C} /{ }^{12} \mathrm{C}, \delta^{13} \mathrm{C}\right)$ and sulphur $\left({ }^{34} \mathrm{~S} /{ }^{32} \mathrm{~S}, \delta^{34} \mathrm{~S}\right)$ are used primarily to determine sources of primary production and are useful to trace the input of these elements into food webs (Krouse \& Herbert 1988, Richards et al. 2003). In particular, the use of $\delta^{34} \mathrm{~S}$ is recommended when the origin of the diet is heterogeneous (Peterson et al. 1985). Stable isotopes of nitrogen $\left({ }^{15} \mathrm{~N} /{ }^{14} \mathrm{~N}, \delta^{15} \mathrm{~N}\right)$ are indicators of food web interactions, and the trophic positions of species as consumers are typically enriched in ${ }^{15} \mathrm{~N}$ relative to their food (Post 2002, Vanderklift \& Ponsard 2003). If isotopic signatures in the tissue of a consumer and its main dietary sources are known and adjusted by the fractionation factors between the tissue and each of the sources (Gannes et al. 1998), we can apply mixing models to obtain an index of the relative contribution made by each kind of prey to the consumer's diet, as long as prey are isotopically distinct (Schwarcz 1991).

Populations of several species of gulls (Larus spp.) have increased dramatically throughout Australia, North America and Europe in the past few decades (Smith \& Carlile 1993, Vidal et al. 1998). These demographic increases have been attributed to several factors (Pons 1992, Bosch et al. 1994, Belant 1997), such as the protection from human disturbance, the increasing availability of anthropogenic food from both periurban open-air refuse dumps and industrial fisheries, and the great ability of gulls to adapt to human-altered environments.

We studied the diet of yellow-legged gulls Larus michahellis. This species breeds around the Mediterranean basin, and is the most common and widespread seabird of the western Mediterranean, where its population reached 120000 nesting pairs (Pérennou et al. 1996), increasing up to $10 \% \mathrm{yr}^{-1}$ (Thibault et al. 1996, Vidal et al. 1998). As a result of its increasing population, the yellow-legged gull has become problematic throughout its Mediterranean range. In most cases it is considered a pest because of its interactions with human populations in airports, cities, arable lands or fisheries. In addition, it interacts with other species, usually under protection, which can be disturbed, predated and displaced by the gulls from their breeding areas (Vidal et al. 1998, Oro \& Martínez-Abraín 2007).

On the other hand, owing to its abundance, wide distribution and opportunistic feeding habits, the yellowlegged gull might also be used to measure the effects of pollution in the Mediterranean area. This is another important aspect of applied ecology in the case of this species, as it benefits from the same resources consumed by humans, as indicated by its use of refuse dumps and fishery discards. Therefore, if this species is to be used for biomonitoring, the foraging habitats and trophic relationships for every population must be determined to correctly interpret the meaning of the observed pollutant levels (Furness \& Camphuysen 1997, Becker 2003, Sanpera et al. 2007).

Our main objective was to isotopically characterise $\left(\delta^{13} \mathrm{C}, \delta^{15} \mathrm{~N}, \delta^{34} \mathrm{~S}\right)$ the diet of yellow-legged gull populations at different localities where they are believed to consume different proportions of marine, terrestrial and garbage resources. We used an approach based on the feeding ecology of nestlings alone. This ensured that the tissues analysed (feathers) were formed exclusively from the dietary inputs received at the colony site (Sanpera et al. 2007), thus avoiding potential problems caused by the seasonal movements of adult populations. Secondly, as few papers have combined direct dietary analysis and indirect mixing models based on isotopic signatures, we aimed to compare results from these 2 approaches and to find appropriate tracers to isotopically define the different food resources exploited by gulls.

\section{MATERIALS AND METHODS}

Study area and sampling strategy. The study was carried out in 4 colonies along the Iberian Mediterranean coast during the chick-rearing period in 2004. From north to south, the sampled colonies were in the Medes Islands, the Ebro Delta, the Columbretes Islands, and Mazarrón Island (Fig. 1). These colonies were chosen because we expected their diets to differ and their stable isotopes to differ accordingly. The Medes Islands $\left(42^{\circ} 0^{\prime} \mathrm{N}, 3^{\circ} 13^{\prime} \mathrm{E}\right)$ lie $900 \mathrm{~m}$ off the coast near a series of tourist towns, and they hold one of the 


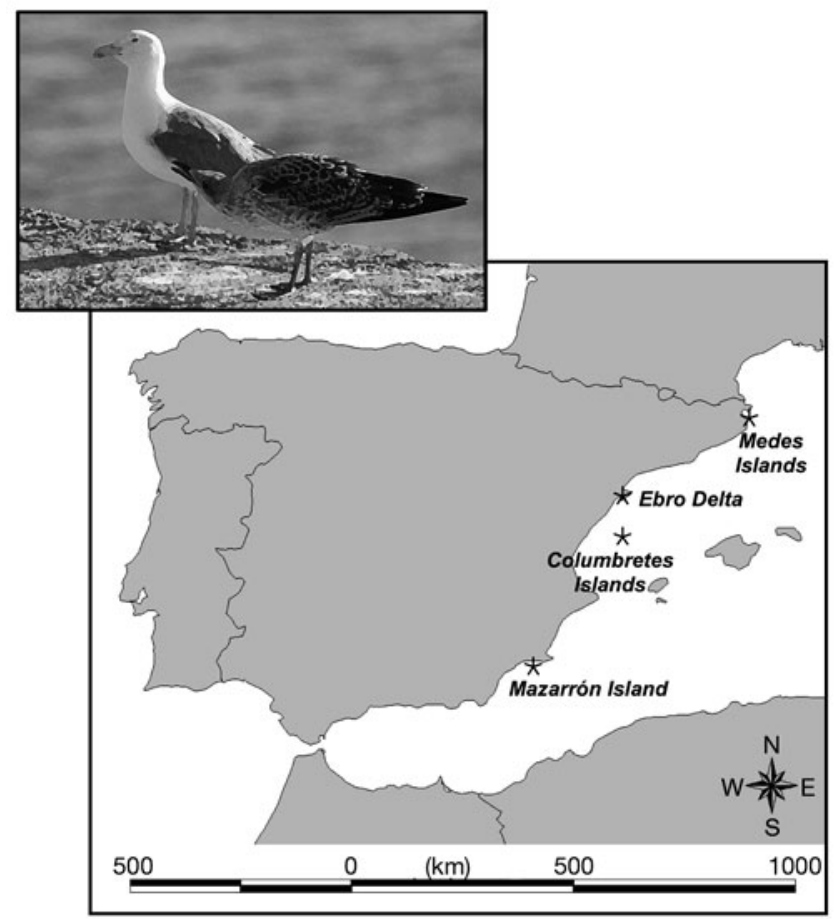

Fig. 1. Larus michahellis. Iberian Peninsula (southwest Europe), indicating breeding colonies included in the study. Photo shows a yellow-legged gull chick begging one of its parents for food

largest colonies of yellow-legged gulls in the Mediterranean (ca. 6650 pairs after several cullings; Bosch et al. 2000). According to Bosch et al. (1994), their diet is mainly composed of garbage from refuse dumps and some fishery discards. About 6000 pairs live in the Ebro Delta colony (Guinart et al. 2004), located on the Peninsula de la Banya $\left(40^{\circ} 40^{\prime} \mathrm{N}, 0^{\circ} 45^{\prime} \mathrm{E}\right)$, a protected area of salt marshes within the Ebro Delta Natural Park, where fishing is intense (Pedrocchi et al. 2002). Previous studies have indicated that the gulls' diet is mainly composed of fishery discards and, to a lesser extent, garbage (Bosch et al. 1994). The Columbretes Islands $\left(39^{\circ} 54^{\prime} \mathrm{N}, 0^{\circ} 41^{\prime} \mathrm{E}\right)$ are a volcanic archipelago, lying $55 \mathrm{~km}$ east off the coast of Castelló. No previous detailed studies were available, but owing to the islands' great distance from the mainland, these birds were expected to feed mainly on fish during the breeding season. Their colony size is the smallest of the 4 colonies sampled, with about 400 breeding pairs (Martínez-Abraín et al. 2003). Mazarrón Island $\left(39^{\circ} 33^{\prime} \mathrm{N}, 1^{\circ} 16^{\prime} \mathrm{W}\right)$ also lies immediately opposite a large tourist town, which is especially well populated during summer. No previous studies on the diet of this colony were available; however, based on previous observations, we expected to find a mixture of garbage and terrestrial prey caught in the very intensive crop fields surrounding the town, as well as some fishery discards.
Each colony was visited 3 times throughout the chickrearing period. During each visit, a single chick was sampled from each brood to avoid pseudoreplication due to parents feeding the same prey to their offspring. Food samples were collected as spontaneous regurgitations ( $\mathrm{n}=356$ ) from chicks when they were handled for marking and measuring. The regurgitates were individually placed in sealed plastic bags and stored at $-20^{\circ} \mathrm{C}$ until laboratory analysis. On the last visit only, when fledglings were available, 6 to 8 growing scapular feathers were collected from each bird $(n=107)$. Scapular feathers from chicks grow slowly and constantly (R. Ramos pers. obs.); thus, we hypothesised that they represent the entire feather-growth period.

Laboratory procedure and stable isotope analysis. In the laboratory, every regurgitate was weighed and identified to the order level using standard reference guides (Ruiz 1985). They were then assigned to 5 categories according to foraging habitat (see Bosch et al. 1994): (1) marine, (2) brackish and fresh waters, (3) crops and terrestrial environments, (4) refuse tips, mainly including food scraps and (5) other. The importance of the different categories in each colony was represented by its percentage biomass. Dietary analyses focused on foraging areas because our previous observations had indicated that differences in prey signatures were different enough to guarantee good discrimination using stable isotope methodology.

Feathers were washed in a $0.25 \mathrm{M}$ sodium hydroxide solution, rinsed thoroughly in distilled water to remove any surface contamination, dried in an oven at $60^{\circ} \mathrm{C}$ to constant mass, and ground to a fine powder in a freezer mill (Spex Certiprep 6750) operating at liquid nitrogen temperature. Additionally, from all available prey we took a sample of the main prey items consumed in each locality to analyse their isotopic signatures. Before isotopic analysis, food samples were freeze-dried and ground to a fine powder in the freezer mill. To reduce variability due to isotopically lighter lipids, which may have a particular influence on carbon isotope ratios (Attwood \& Peterson 1989, Hobson \& Welch 1992), lipids were removed by the Folch extraction method (Folch et al. 1957) with several chloroform-methanol $(2: 1)$ rinses.

Subsamples of $0.4 \mathrm{mg}$ of feather powder for carbon and nitrogen and about $3.5 \mathrm{mg}$ for sulphur analyses were weighed to the nearest $\mu \mathrm{g}$, placed into tin capsules and crimped for combustion. Samples were oxidised in a Flash EA1112 coupled to a stable isotope mass spectrometer Delta $\mathrm{C}$ through a Conflo III interface (ThermoFinnigan), where the $\delta^{13} \mathrm{C}, \delta^{15} \mathrm{~N}$ and $\delta^{34} \mathrm{~S}$ values were determined.

Isotope ratios are expressed conventionally as $\delta$ values in parts per thousand (\%) according to the following equation: 


$$
\delta X=\left[\left(R_{\text {sample }} / R_{\text {standard }}\right)-1\right] \times 1000
$$

where $X(\%)$ is ${ }^{13} \mathrm{C}^{15} \mathrm{~N}$ or ${ }^{34} \mathrm{~S}$, and $R$ is the ratio of corresponding element $\left({ }^{13} \mathrm{C} /{ }^{12} \mathrm{C},{ }^{15} \mathrm{~N} /{ }^{14} \mathrm{~N}\right.$ or $\left.{ }^{34} \mathrm{~S} /{ }^{32} \mathrm{~S}\right)$, in sample or standard. The standard values were Pee Dee Belemnite for ${ }^{13} \mathrm{C}$, atmospheric nitrogen for ${ }^{15} \mathrm{~N}$ and troilite from the Canyon Diablo Meteorite for ${ }^{34} \mathrm{~S}$. The isotopic ratio mass spectrometry facility at the Serveis Científico-Tècnics of the University of Barcelona (Spain) applies IAEA standards inserted every 12 samples to calibrate the system. Replicate assays of standards indicated measurement errors of $\pm 0.1, \pm 0.2$ and $\pm 0.2 \%$ for carbon, nitrogen and sulphur, respectively, but these are likely to be underestimates of true measurement error for complex organics like feathers.

Isotopic mixing models and statistical analysis. Relative indices of the different food sources were estimated for each population using $\delta^{13} \mathrm{C}, \delta^{15} \mathrm{~N}$ and $\delta^{34} \mathrm{~S}$ mean values in a concentration-weighted mixing model. When isotope values differ substantially among the sources, a concentration-weighted model is recommended (Phillips \& Koch 2002). Following Phillips \& Koch (2002), we used the ISOCONC 1.01 model suitably modified to use 4 food sources and 3 stable isotope signatures. To apply mixing models, isotopic values for food sources must be adjusted by appropriate factors $(\Delta \mathrm{dt})$ to account for trophic fractionation (Gannes et al. 1998). The fractionation factor for marine fish and feathers was established from Columbretes Islands data, as only marine food resources were used there. We used $\Delta \mathrm{dt}$ values from the literature for the other food categories (Table 1). When negative values near 0 were generated by the mixing model, percentages were readjusted for each locality, setting the most negative value to 0 and recomputing other percentages according to the original proportions given by the model.

Intercolony differences in biomass percentages of prey were identified using a Kruskal-Wallis test fol- lowed by a Mann-Whitney pair-comparison test with Bonferroni adjustment. Normality checks for distributions of values of $\delta^{13} \mathrm{C}, \delta^{15} \mathrm{~N}$ and $\delta^{34} \mathrm{~S}$ were made using $\mathrm{Q}-\mathrm{Q}$ plots. No severe deviations from normality were found, and we used parametric tests throughout. Because variances were found to be heterogeneous, isotopic differences between localities were analysed using 1-way analysis of variance (ANOVA) with Welch's correction. Tamhane's test procedure was used in a posteriori pairwise comparisons. Spearman correlations were used to examine relationships between isotope data and measurements of marine prey consumption at the colony level. To compare the 2 approaches, we represented the single values derived from mixing models (converted to weights using the mean weight of all regurgitates) with the error bars for each foraging habitat (with mean and $95 \%$ confidence intervals) computed from conventional dietary analysis. Statistical analysis was carried out using SPSS 15.0.

\section{RESULTS}

\section{Diet analysis}

According to diet biomass percentages (Fig. 2), the gulls used 3 main foraging habitats: marine environments, refuse tips and brackish and freshwater marshes. Total regurgitates from these 3 habitats respectively represented $98.2,90.3,92.7$ and $89.6 \%$ of total biomass in the Columbretes, Ebro Delta, Medes and Mazarrón colonies. Prey from marine environments occurred in diets at all 4 localities, while food from refuse tips was only present in the diets at 3 sites. However, only garbage was relevant in the Medes site $(45.4 \%)$ and the Mazarrón site $(43.8 \%)$, and it was poorly represented in the Ebro Delta site $(8.5 \%)$. As expected, the Columbretes population did not exhibit

Table 1. Diet-tissue isotope-fractionation factors $\left(\Delta^{13} \mathrm{C}, \Delta^{15} \mathrm{~N}\right.$ and $\left.\Delta^{34} \mathrm{~S}\right)$ between consumers' feathers and different food sources extracted from the literature

\begin{tabular}{|c|c|c|c|c|c|}
\hline Prey class & Consumer-diet & $\begin{array}{l}\text { Diet-tiss } \\
\Delta^{13} \mathrm{C}(\% \text { o })\end{array}$ & $\begin{array}{l}\text { ue discrimi } \\
\Delta^{15} \mathrm{~N}(\%)\end{array}$ & $\begin{array}{l}\text { hation } \\
\Delta^{34} \mathrm{~S}(\% \text { o) }\end{array}$ & Source \\
\hline Marine & Larus michahellis-marine fish & 0.9 & 1.7 & 1.9 & The present study \\
\hline Freshwater invertebrates & Larus delawarensis-freshwater food & d $\quad 0.3$ & 3.0 & $1.3^{\mathrm{a}}$ & $\begin{array}{l}\text { Hobson \& Clark (1992) } \\
\text { France \& Peters (1997) } \\
\text { Peterson et al. (1985) }\end{array}$ \\
\hline Terrestrial invertebrates & Sylvia borin-mealworms & 2.7 & 4 & $1.3^{\mathrm{a}}$ & $\begin{array}{l}\text { Hobson \& Bairlein (2003) } \\
\text { Peterson et al. (1985) }\end{array}$ \\
\hline Refuse tips & Catharacta skua-beef ${ }^{\mathrm{b}}$ & 2.2 & 5.0 & $1.3^{\mathrm{a}}$ & $\begin{array}{l}\text { Bearhop et al. (2002) } \\
\text { Peterson et al. (1985) }\end{array}$ \\
\hline
\end{tabular}



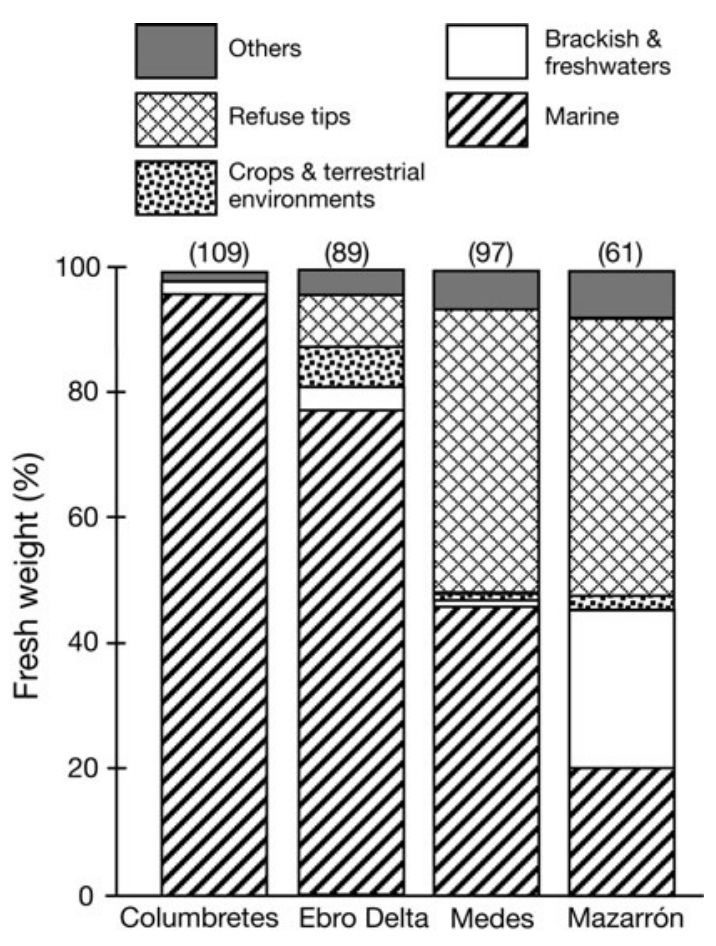

Fig. 2. Larus michahellis. Fresh weight percentages of prey according to the main foraging habitats indicated in regurgitates of yellow-legged gull chicks (sample size in brackets)

food from refuse tips, with most food coming from the sea $(96.3 \%)$. Significant differences were found between biomass percentages of marine prey (KruskalWallis, $H_{3}=101.16, \mathrm{p}<0.001$ ) in the 4 localities. All of them were compared and were significantly different, except the Ebro Delta-Medes and Medes-Mazarrón pairs. On the other hand, prey from brackish and freshwater habitats were only common in regurgitates from Mazarrón (25.5\%; Fig. 2).

\section{Stable isotope analysis and mixing models}

Values of $\delta^{13} \mathrm{C}$ in feathers showed significant differences between localities $\left(F_{\text {Welch } 3,23}=69.06\right.$, p $<0.001$; Fig. 3a,b). Post hoc comparisons showed that Columbretes chicks had the highest $\delta^{13} \mathrm{C}$ values $(-17.49 \pm$ $0.18 ; \mathrm{n}=42)$. Ebro Delta and Medes Islands chicks showed intermediate values $(-18.19 \pm 0.32 ; \mathrm{n}=23$ and $-18.37 \pm 0.49 ; \mathrm{n}=22$, respectively), which were not significantly different, whereas Mazarrón chicks $(-18.76 \pm 0.61 ; \mathrm{n}=20)$ showed the lowest values, which were different from those of the Ebro Delta but not different from those of the Medes colony. At the colony level, we found a high, significantly positive correlation between mean $\delta^{13} \mathrm{C}$ values and marine prey
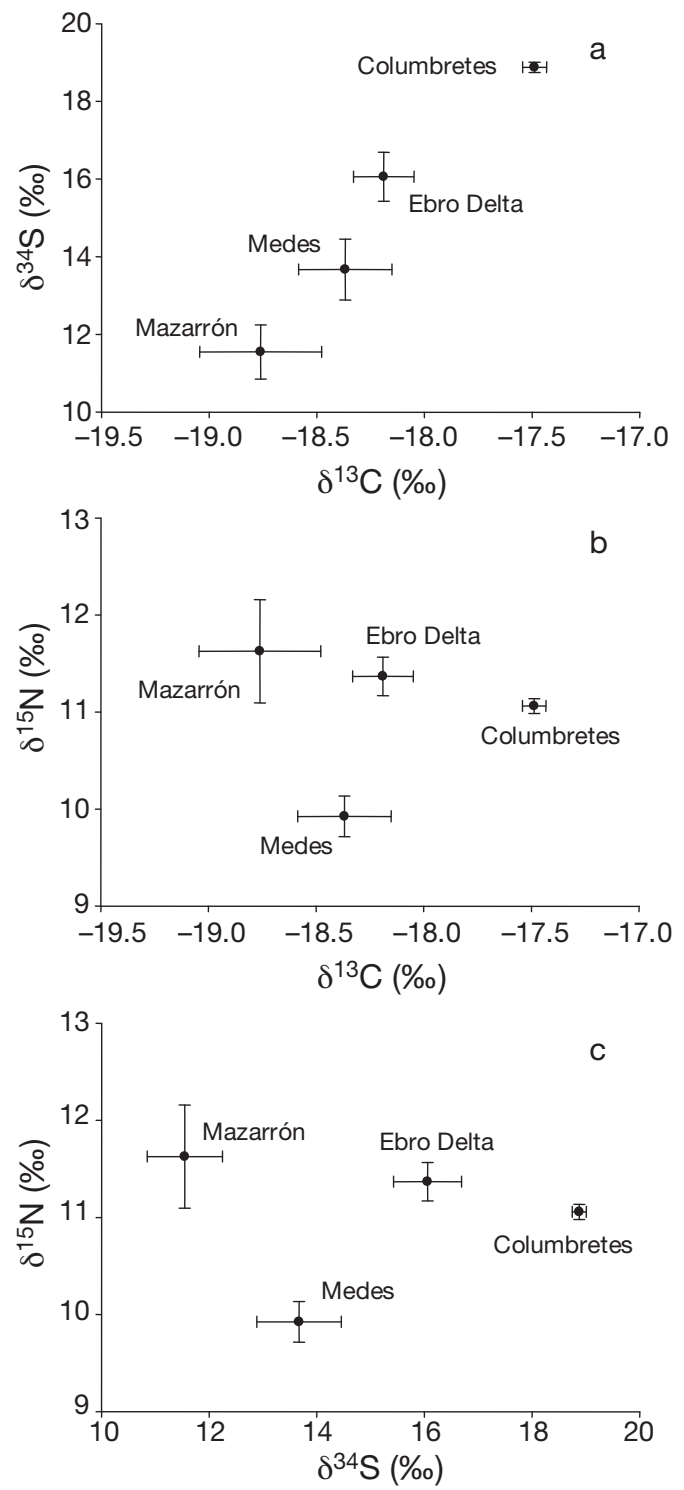

Fig. 3. Larus michahellis. Mean (95\% CI) (a) sulphur-carbon, (b) nitrogen-carbon and (c) nitrogen-sulphur isotope signatures in feathers of fledglings in relation to the breeding colony (sample size is 42, 23, 22 and 20 for the Columbretes, Ebro Delta, Medes and Mazarrón colonies, respectively)

consumption $\left(r_{S}=1.00, \mathrm{p}<0.001, \mathrm{n}=4\right)$. Feathers also exhibited significant differences between localities in $\delta^{15} \mathrm{~N}\left(F_{\text {Welch 3,23 }}=44.08, \mathrm{p}<0.001\right.$; Fig. 3b,c). Post hoc comparisons showed that values from Columbretes $(11.06 \pm 0.25)$, Ebro $(11.37 \pm 0.46)$ and Mazarrón $(11.63 \pm 1.14)$ were similar, whereas values from the Medes site $(9.92 \pm 0.47)$ were significantly lower. Mean $\delta^{15} \mathrm{~N}$ values exhibited no relationship with consumption of fish $\left(r_{S}=-0.40, \mathrm{p}<0.60, \mathrm{n}=4\right)$. The $\delta^{34} \mathrm{~S}$ values of feathers differed between localities ( $F_{\text {Welch } 3,23}=$ 222.46, $\mathrm{p}<0.001$; Fig. 3a,c) in the same direction 
Table 2. Summary of mean isotope values $( \pm \mathrm{SE})$ for the main kind of resources found in chick regurgitates and their significance ( $\mathrm{p}$ values) in differences among colonies

\begin{tabular}{|c|c|c|c|c|c|c|c|}
\hline Prey class & $\mathrm{n}$ & $\delta^{13} \mathrm{C}(\%)$ & $\mathrm{p}$ & $\delta^{15} \mathrm{~N}(\%)$ & $\mathrm{p}$ & $\delta^{34} \mathrm{~S}(\%)$ & $\mathrm{p}$ \\
\hline Marine & 29 & $-18.38 \pm 0.73$ & 0.113 & $9.64 \pm 0.97$ & 0.808 & $16.93 \pm 1.52$ & 0.214 \\
\hline Freshwater invertebrates $^{a}$ & 4 & $-18.87 \pm 0.69$ & - & $9.91 \pm 2.81$ & - & $10.12 \pm 0.89$ & - \\
\hline Terrestrial invertebrates & 11 & $-18.38 \pm 1.75$ & 0.667 & $11.92 \pm 3.00$ & 0.350 & $6.97 \pm 1.05$ & 0.718 \\
\hline Refuse tips & 12 & $-21.67 \pm 1.44$ & 0.010 & $5.50 \pm 1.74$ & 0.597 & $6.72 \pm 2.03$ & 0.232 \\
\hline
\end{tabular}

apparent in $\delta^{13} \mathrm{C}$ values, although with a higher discrimination power. The post hoc Tamhane's procedure exhibited 4 significantly different groups. Feathers from Columbretes $(18.88 \pm 0.42)$ exhibited higher $\delta^{34} \mathrm{~S}$ values than those of Mazarrón (11.56 \pm 1.49$)$. The Ebro Delta and Medes sites had intermediate values $(16.06 \pm 1.46$ and $13.67 \pm 1.77$, respectively). A strong positive correlation was found between mean $\delta^{34} \mathrm{~S}$ values and marine prey (mostly fish) consumption $\left(r_{S}=\right.$ 1.00, $\mathrm{p}<0.001, \mathrm{n}=4$ ).

Related to potential differences in baseline isotope signatures among colonies (see Hebert et al. 1999), no consistent intercolony differences were found in the main food categories for $\delta^{13} \mathrm{C}, \delta^{15} \mathrm{~N}$ or $\delta^{34} \mathrm{~S}$ values (see Table 2 for significance values). Values of $\delta^{13} \mathrm{C}$ and $\delta^{15} \mathrm{~N}$ for garbage were significantly lower than those for both fish and invertebrates $\left(F_{\text {Welch 3,14 }}=15.33, \mathrm{p}<\right.$ 0.001 and $F_{\text {Welch } 3,12}=19.08, \mathrm{p}<0.001$, respectively; post hoc Tamhane's multiple comparison test, $\mathrm{p}<0.05$ ), whereas $\delta^{34} \mathrm{~S}$ showed a different pattern: signatures of refuse tips and terrestrial invertebrates were lower

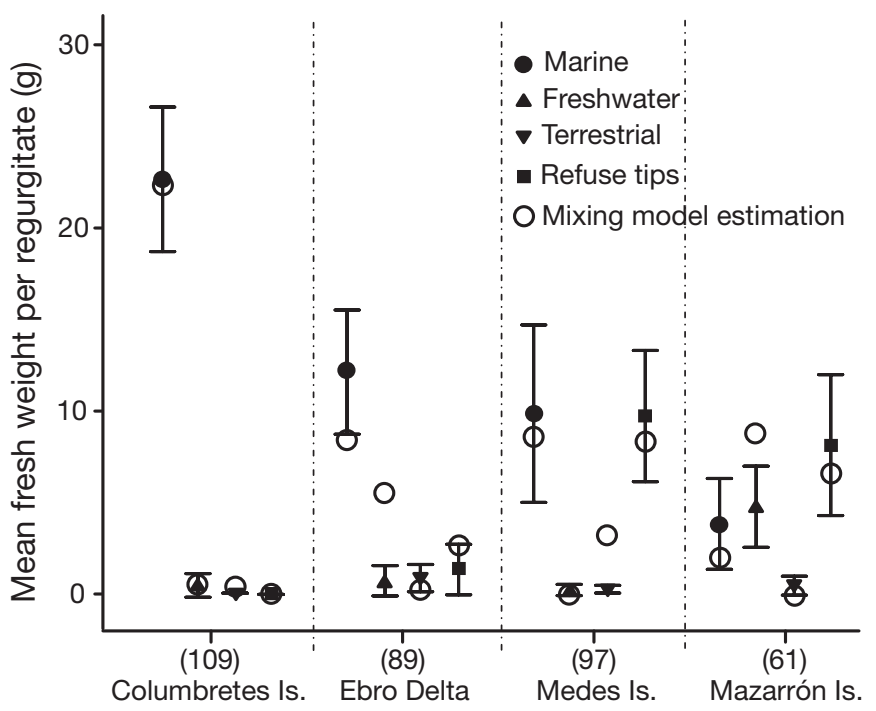

Fig. 4. Mean fresh weight per regurgitate (95\% CI) of different foraging habitats computed from direct diet sampling (sample size in brackets). Mean weights of each foraging habitat estimated by the mixing model are also indicated than those of freshwater invertebrates. Freshwater invertebrates showed lower $\delta^{34} \mathrm{~S}$ values than those of fish $\left(F_{\text {Welch 3,14 }}=227.54, \mathrm{p}<0.001\right.$; post hoc Tamhane's multiple comparison test, $\mathrm{p}<0.05)$.

Carbon, nitrogen and sulphur concentrations were significantly different in the different food sources (1-way ANOVA; $F_{3,55}=15.23, F_{3,55}=23.30$ and $F_{3,55}=$ 4.61 respectively, all $\mathrm{p}<0.001$ ), justifying the use of a concentration-weighted mixing model (see Phillips \& Koch 2002; Fig. 4). The model indicated that most of the prey consumed in Columbretes came from marine environments. For the Ebro Delta colony, the model estimated that half of the food was from marine sources, almost a third was freshwater invertebrates and a small amount was from refuse tips $(15.3 \%)$. For the Medes site, the importance of both marine prey and garbage was around $40 \%$, whereas terrestrial invertebrates represented almost $20 \%$ of ingested food. Finally, for the Mazarrón site, the mixing model indicated freshwater environments to be the most exploited food source $(46 \%)$, although garbage $(34.4 \%)$ and marine prey $(19.6 \%)$ were also significant.

\section{DISCUSSION}

\section{Feeding ecology of gulls}

Isotope signatures as well as the information obtained from chick regurgitates showed substantial differences among localities, particularly in the exploitation of marine environments (Figs. 2 \& 4). These differences can be explained by the availability per capita (i.e. related to the colony size) of this food resource, as well as by the presence of other alternative foods easier to obtain than marine prey, such as garbage from refuse tips. Refuse, consisting primarily of chicken, pork, and beef scraps, is easy to obtain if it is abundant and close to the breeding colony, and it has high values in energy per meal and fat and protein per gram (Pierotti \& Annet 1991). This explains its high proportion in diets of gull colonies with nearby dense human populations, such as those at the Medes and Mazarrón sites. The lower proportion of refuse in the 
diet of the Ebro Delta birds compared to those from Medes might be related to its lower availability. Indeed, refuse tips in the Medes Islands are 5 times more abundant than those of the Ebro Delta (Bosch et al. 1994). At Columbretes, the mainland is too far away, and consequently chicks are mainly fed marine fish collected by the parents (i.e. through association with sub-surface predators; Oro 1995) or from fishery discards of the fishing fleet operating in this area (R. Ramos pers. obs.; Oro et al. 1996).

Both methodologies showed that prey related to human activities, such as garbage or fish discards (Witt et al. 1981), were the main components of chick diets in the sampled colonies, comprising more than $80 \%$ of the total diet biomass in 3 localities, while at the other site (Mazarrón) this value was 60 to $65 \%$ (Figs. 2 \& 4). On the other hand, nearby environments, such as freshwater sources or crops, were also exploited during the breeding season, especially in those populations associated with continental environments. However, their relevance mainly depends on the study methodology chosen, which suggests some drawbacks (see below). This heterogeneity in foraging habitats, exploited both within and among populations, according to their availability indicates the generalist and opportunistic feeding habits of this species (see Bosch et al. 1994) and emphasises the importance of a technique allowing a quick assessment of yearly changes in every population.

\section{Isotopic tracers in feeding ecology}

As we did not find differences in the isotopic signatures within each of the main prey categories among localities, the considerable isotopic variation among feathers from different colonies was related to differences in diet composition (see Hebert et al. 1999). In agreement with previous studies, we found that $\delta^{13} \mathrm{C}$ and $\delta^{34} \mathrm{~S}$ levels were higher as the consumption of marine prey increased (France \& Peters 1997, Knoff et al. 2002). However, only sulphur signatures differed enough among all prey types (Table 2) to be considered a useful tracer to assess the origin of the food consumed (see Hobson 1999). On the other hand, carbon signatures of the main prey types were rather similar, except garbage values, suggesting that the correlation between $\delta^{13} \mathrm{C}$ and the consumption of marine prey could be a secondary effect derived from garbage consumption, since the proportions of both resources in the diet are roughly complementary. Thus, $\delta^{34} \mathrm{~S}$ seems to have a greater discrimination power (Fig. 3a) that allowed us to distinguish between continental-terrestrial and marine-based diets even better than with $\delta^{13} \mathrm{C}$ (but see Knoff et al. 2002). Therefore, $\delta^{34} \mathrm{~S}$ can be used as an integrated measurement of marine food consumption throughout the nestling growth period. We found that samples from refuse tips provided the lowest values for $\delta^{13} \mathrm{C}, \delta^{15} \mathrm{~N}$ and $\delta^{34} \mathrm{~S}$ (Table 2) and consequently, the Medes and Mazarrón sites, due to the consumption of garbage by gulls, showed the lowest values for these isotopes (Fig. 3). We expected $\delta^{15} \mathrm{~N}$ values from refuse tips to be the least enriched owing to a short food chain (Hebert et al. 1999). Accordingly, $\delta^{15} \mathrm{~N}$ values of the Medes colony were significantly lower than those from other localities (Fig. 3b,c), since almost half of its dietary biomass came from refuse tips (Fig. 2). Nevertheless, it should be noted that at the Mazarrón site, although almost half of the chicks' dietary biomass also came from refuse tips, $\delta^{15} \mathrm{~N}$ values were relatively high (Fig. 3b,c). This unexpected high value can be explained by taking into account that freshwater invertebrates show high $\delta^{15} \mathrm{~N}$ values (Table 2) and that a moderate consumption of that resource might substantially increase $\delta^{15} \mathrm{~N}$ values of consumers (Vanderklift \& Ponsard 2003). We would not have known this had we not collected direct as well as indirect samples. The fact that these invertebrates were mostly involved in food webs based on dead organic matter might explain their high $\delta^{15} \mathrm{~N}$ signatures (Ponsard \& Arditi 2000)

\section{Comparing diet analysis and mixing models}

The main pattern resulting from the mixing model values was in agreement with the direct method to determine diets, although some of the estimated weights provided by mixing models did not fit into confidence intervals computed from regurgitate analysis (Fig. 4). Whereas the relative weights of marine and garbage resources agreed between both methodologies, estimations for some of the invertebrates (both from freshwater and terrestrial environments) were higher in the mixing model than in the regurgitate analysis. Indeed, regurgitate analyses underestimate the importance of small and soft prey items, such as invertebrates, while larger and harder prey are overestimated (Duffy \& Jackson 1986, Hobson \& Clark 1992), suggesting that isotopic results are necessary to fully describe diet.

Despite some problems found with the mixing model, probably derived from inaccurate fractionation assumptions (Phillips \& Koch 2002), it helped us to estimate diet composition with minimum disturbance to the birds (Hodum \& Hobson 2000, Ben-David \& Schell 2001). Moreover, mixing models overcome problems of over- or underestimations related to digestibility of prey items (Croxall et al. 1997), as only assimilated food is considered. However, other prob- 
lems arose, with fractionation factors being crucial. In this respect, very few papers have reported the fractionation between a consumer's tissue and a particular kind of dietary resource; most studies have measured fractionation factors according to whole diet without taking into account different diet components (but see Hobson \& Bairlein 2003, Pearson et al. 2003). To solve the problem regarding the lack of precise fractionation factors, future experimental studies should be carried out to account for different kinds of diets as well as different consumer tissues, although difficulties in obtaining experimental diets based on only a single resource, like invertebrates, are well known.

Another restriction imposed by the mixing model approach was related to the taxonomic precision of the results, which are rather coarse compared to the exhaustive detail achieved by direct dietary analysis. For instance, as noted above, we would not have resolved the importance of freshwater contributions without direct samples. However, the information provided by stable isotopes about the feeding ecology of a generalist species was enough to obtain a general idea of the use of different foraging habitats exploited by these birds.

\section{CONCLUSIONS AND APPLICATIONS}

In the present study we have shown that the combined analysis of isotopic signatures of carbon, nitrogen and sulphur in fledgling feathers of yellow-legged gulls can characterise the different proportions of feeding resources from marine habitats, brackish and freshwater environments, crops and refuse tips. In particular, $\delta^{34} \mathrm{~S}$ signatures discriminated among marine and freshwater-terrestrial origins of dietary resources, while a depleted $\delta^{15} \mathrm{~N}$ resulted from the exploitation of refuse tips. Although the taxonomic detail achieved by direct dietary analysis was not obtained, mixing models have become useful in the study of feeding ecology of populations or species that are highly opportunistic in their feeding habits and hence able to rapidly change the resources used. This is particularly relevant to correctly interpreting comparisons among populations about pollutant levels accumulated, or in ascertaining the provenance of such pollutants. However, exhaustive captive-feeding experiments should be carried out to determine the specific fractionation factors between a consumer's tissue and its diet. We stress the use of feathers in the study of the feeding ecology because feathers are sufficiently powerful and easy to sample and could be particularly useful in studies of endangered species by minimising disturbance to sampled populations.
Isotope signatures provide an integrative view on assimilated diets instead of the discrete information obtained from ingested resources. Whereas conventional dietary analysis requires exhaustive monitoring over time to obtain reliable information, SIA only needs single sampling depending on the tissue available. Moreover, direct dietary analysis produced slight under- and overestimations derived from the differential digestibility of prey. Thus, the information generated by isotopes, especially if calibrated from analysis of direct samples, is a reliable method to determine the importance of certain exploited resources.

Acknowledgements. We dedicate this article to the memory of Xavier Ruiz, who unexpectedly died on 27 April 2008 while the manuscript was in review. We thank the wildlife authorities of the respective communities for permission to conduct this study. We thank the wardens of Columbretes Islands, especially R. Belenguer, M. Prados and V. Tena, for their warm welcome and their invaluable assistance with the fieldwork. We also thank our Journal Club colleagues for reviewing an earlier draft of the manuscript as well as 2 anonymous referees for helpful suggestions. R.R. was supported by a Formación de Personal Universitario (FPU) grant awarded by the Spanish Ministerio de Educación y Ciencia (MEyC). Financial support was provided by grants REN2003-07050 and VEM 2004-08524 from the MEyC.

\section{LITERATURE CITED}

Attwood CG, Peterson WT (1989) Reduction in fecundity and lipids of the copepod Calanus australis (Brodskii) by strongly pulsed upwelling. J Exp Mar Biol Ecol 129:121-131

> Barrett RT, Camphuysen CJ, Anker-Nilssen T, Chardine JW and others (2007) Diet studies of seabirds: a review and recommendations. ICES J Mar Sci 64:1675-1691

Bearhop S, Waldron S, Votier SC, Furness RW (2002) Factors that influence assimilation rates and fractionation of nitrogen and carbon stable isotopes in avian blood and feathers. Physiol Biochem Zool 75:451-458

Becker PH (2003) Biomonitoring with birds. In: Markert BA, Breure AM, Zechmeister HG (eds) Bioindicators and biomonitors. Elsevier, Amsterdam, p 677-736

Belant JL (1997) Gulls in urban environments: landscapelevel management to reduce conflict. Landsc Urban Plann 38:245-258

> Ben-David M, Schell DM (2001) Mixing models in analyses of diet using multiple stable isotopes: a response. Oecologia 127:180-184

Bosch M, Oro D, Ruiz X (1994) Dependence of yellow-legged gulls (Larus cachinnans) on food from human activity in two western Mediterranean colonies. Avocetta 18:135-139

Bosch M, Oro D, Cantos FJ, Zabala M (2000) Short-term effects of culling on the ecology and population dynamics of the yellow-legged gull. J Appl Ecol 37:369-385

> Cherel Y, Hobson KA, Guinet C, Vanpe C (2007) Stable isotopes document seasonal changes in trophic niches and winter foraging individual specialization in diving predators from the Southern Ocean. J Anim Ecol 76:826-836

Croxall JP, Prince PA, Reid K (1997) Dietary segregation of krill-eating South Georgia seabirds. J Zool (Lond) 242: 531-556 
Duffy DC, Jackson S (1986) Diet studies of seabirds: a review of methods. Colon Waterbirds 9:1-17

Folch J, Lees M, Sloane-Stanley GH (1957) A simple method for the isolation and purification of total lipides from animal tissues. J Biol Chem 226:497-509

France RL, Peters RH (1997) Ecosystem differences in the trophic enrichment of ${ }^{13} \mathrm{C}$ in aquatic food webs. Can J Fish Aquat Sci 54:1255-1258

Furness RW, Camphuysen CJ (1997) Seabirds as monitors of the marine environment. ICES J Mar Sci 54:726-737

> Gannes LZ, del Rio CM, Koch P (1998) Natural abundance variations in stable isotopes and their potential uses in animal physiological ecology: implication for $\delta^{13} \mathrm{C}$ analysis of diet. Comp Biochem Physiol A 119:725-737

González-Solís J, Oro D, Pedrocchi V, Jover L, Ruiz X (1997) Bias associated with diet samples in Audouin's gulls. Condor 99:773-779

Guinart E, Vidal F, Ruiz-Olmo J, Gutiérrez R, Blanch F, Bigas D (2004) Se ensaya la creación de nuevas colonias. Iniciativas para mejorar la situación de la gaviota de Audouin en Cataluña. Quercus 221:12-19

> Hebert CE, Shutt JL, Hobson KA, Weseloh DVC (1999) Spatial and temporal differences in the diet of Great Lakes herring gulls (Larus argentatus): evidences from stable isotope analysis. Can J Fish Aquat Sci 56:323-338

Hobson KA (1999) Tracing origins and migration of wildlife using stable isotopes: a review. Oecologia 120:314-326

Hobson KA, Bairlein F (2003) Isotopic fractionation and turnover in captive Garden Warblers (Sylvia borin): implications for delineating dietary and migratory associations in wild passerines. Can J Zool 81:1630-1635

Hobson KA, Clark RG (1992) Assessing avian diets using stable isotopes II: factors influencing diet-tissue fractionation. Condor 94:189-197

Hobson KA, Welch HE (1992) Determination of trophic relationships within a high Arctic marine food web using $\delta^{13} \mathrm{C}$ and $\delta^{15} \mathrm{~N}$ analysis. Mar Ecol Prog Ser 84:9-18

Hodum PJ, Hobson KA (2000) Trophic relationships among Antarctic fulmarine petrels: insights into dietary overlap and chick provisioning strategies inferred from stableisotope $\left(\delta^{15} \mathrm{~N}\right.$ and $\left.\delta^{13} \mathrm{C}\right)$ analyses. Mar Ecol Prog Ser 198: $273-281$

Jordan MJR (2005) Dietary analysis for mammals and birds: a review of field techniques and animal-management applications. Int Zoo Yearb 39:108-116

Knoff AJ, Macko SA, Erwin RM, Brown KM (2002) Stable isotope analysis of temporal variation in the diets of prefledged laughing gulls. Waterbirds 25:142-148

Krouse HR, Herbert HK (1988) Sulphur and carbon isotope studies of food webs. In: Kennedy BV, LeMoine GM (eds) Diet and subsistence: current archaeological perspectives. University of Calgary Archaeology Association, Calgary, p 315-322

Martínez-Abraín A, Oro D, Izquierdo J, Ferrís V, Belenguer R (2003) A comparison of two methods to estimate breeding productivity in a colonial ground-nesting gull Larus cachinnans. Mar Ornithol 31:63-66

> Oro D (1995) Audouin's Gulls Larus audouinii associate with sub-surface predators in the Mediterranean Sea. J Ornithol 136:465-467

> Oro D, Martínez-Abraín A (2007) Deconstructing myths on large gulls and their impact on threatened sympatric waterbirds. Anim Conserv 10:117-126

Oro D, Genovart X, Ruiz X, Jimenez J, Garciagans J (1996) Differences in diet, population size and reproductive performance between two colonies of Audouin's gull Larus audouinii affected by a trawling moratorium. J Avian Biol
27:245-251

Pearson SF, Levey DJ, Greenberg CH, Martínez del Rio C (2003) Effects of elemental composition on the incorporation of dietary nitrogen and carbon isotopic signatures in an omnivorous songbird. Oecologia 135:516-523

Pedrocchi V, Oro D, González-Solís J, Ruiz X, Jover L (2002) Differences in diet between the two largest breeding colonies of Audouin's gulls: the effect of fishery activities. Sci Mar 66:313-320

Pérennou C, Sadoul N, Pineau O, Johnson A, Hafner H (1996) Management of nest sites for colonial waterbirds. In: Crivelli AJ, Jalbert J (eds) Conservation of Mediterranean wetlands. Tour du Valat Publications, Arles

Peterson BJ, Howarth RW, Garritt RH (1985) Multiple stable isotopes used to trace the flow of organic matter in estuarine food webs. Science 227:1361-1363

Phillips DL, Koch PL (2002) Incorporating concentration dependence in stable isotope mixing models. Oecologia 130: 114-125

> Pierotti R, Annet CA (1991) Diet choice in the herring gull: constraints imposed by reproductive and ecological factors. Ecology 72:319-328

Pons JM (1992) Effects of changes in the availability of human refuse on breeding parameters in a herring gull Larus argentatus population in Brittany, France. Ardea 80: $143-150$

Ponsard S, Arditi R (2000) What can stable isotopes $\left(\delta^{15} \mathrm{~N}\right.$ and $\left.\delta^{13} \mathrm{C}\right)$ tell about the food web of soil macro-invertebrates? Ecology 81:852-864

Post DM (2002) Using stable isotopes to estimate trophic position: models, methods, and assumptions. Ecology 83: 703-718

Richards MP, Fuller BT, Sponheimer M, Robinson T, Ayliffe L (2003) Sulphur isotopes in palaeodietary studies: a review and results from a controlled feeding experiment. Int J Osteoarchaeol 13:37-45

Ruiz X (1985) An analysis of the diet of cattle egrets in the Ebro Delta, Spain. Ardea 73:49-60

Sanpera C, Moreno R, Ruiz X, Jover L (2007) Audouin's gull chicks as bioindicators of mercury pollution at different breeding locations in the western Mediterranean. Mar Pollut Bull 54:691-696

Schwarcz HP (1991) Some theoretical aspects of isotope paleodiet studies. J Archaeol Sci 18:261-275

> Smith GC, Carlile N (1993) Methods for population control within a silver gull colony. Wildl Res 20:219-226

> Thibault JC, Zotier R, Guyot I, Bretagnolle V (1996) Recent trends in breeding marine birds of the Mediterranean Region with special reference to Corsica. Colon Waterbirds 19:31-40

Vanderklift MA, Ponsard S (2003) Sources of variation in a consumer-diet $\delta^{15} \mathrm{~N}$ enrichment: a meta-analysis. Oecologia 136:169-182

Vidal E, Medail F, Tatoni T (1998) Is the yellow-legged gull a superabundant bird species in the Mediterranean? Impact on fauna and flora, conservation measures and research priorities. Biodivers Conserv 7:1013-1026

Votier SC, Bearhop S, Ratcliffe N, Furness RW (2001) Pellets as indicators of diet in great skuas Catharacta skua. Bird Study 48:373-376

Votier SC, Bearhop S, MacCormick A, Ratcliffe N, Furness RW (2003) Assessing the diet of great skuas, Catharacta skua, using five different techniques. Polar Biol 26:20-26

Witt HH, Crespo J, De Juana E, Varela JM (1981) Comparative feeding ecology of Audouin's gull Larus audouinii and the herring gull $L$. argentatus in the Mediterranean. Ibis 123:519-526

Submitted: August 11, 2008; Accepted: October 22, 2008

Proofs received from author(s): January 5, 2009 